\section{Humanistyka medyczna: o leczeniu (się) w patosystemie}

Agnieszka Dauksza

TEKSTY DRUGIE 2021, NR 1, S. 38-58

DOI: 10.18318/td.2021.1.3 | ORCID: 0000-0001-8269-6096

$\mathbf{S}^{\mathrm{s}}$ oje z preparatami anatomicznymi to jeden z najwcześniejszych obrazów dzieciństwa. Nigdy wcześniej (i później) nie żałowałam tak bardzo, że nie umiem czytać. Jako trzy- lub czterolatka poszłam z tatą do gdańskiego Zakładu Patomorfologii. Tylko na chwilę, do sekretariatu, ale droga na piętro wiodła przez szatnie lub coś, co przypominało szatnie z przedszkola. Boksy z metalowymi ławami, następnie sala z dużym, centralnie ulokowanym stołem. Były puste - inaczej nie mogłabym tamtędy przechodzić - spytałam więc, do czego służą. Dzięki odpowiedzi łatwiej było sobie wyobrazić, jaka jest zawartość słojów ustawionych na regałach, które ciągnęły się wzdłuż korytarza na piętrze. Gruźlicze płuca, zdeformowane płody, guzy, narośle, serca z defektem, zmienione nowotworowo wątroby i języki, rozcięte gałki oczne. Właśnie tych określeń brakowało, tabliczki z krzaczastymi opisami mówiły jeszcze mniej niż różowa, sina i sczerniała materia. Zostałam sama na korytarzu i przez kilka, może kilkanaście minut konfrontowałam się z czymś, co podobno było ludzkim ciałem, choć nie
Badania wykonano przy wsparciu finansowym Priorytetowego Obszaru Badawczego Heritage w ramach Programu Strategicznego Inicjatywa Doskonałości w Uniwersytecie Jagiellońskim, edycja I.

Agnieszka Dauksza

- pracuje w Katedrze Antropologii Literatury i Badań Kulturowych WP UJ. Autorka książek: Jaremianka. Biografia (2019), Afektywny modernizm. Nowoczesna literatura polska winterpretacji relacyjnej (2017), Klub Auschwitzi inne kluby (2016, II wyd. 2021) i Kobiety na drodze.

Doświadczenie przestrzeni publicznej w literaturze przełomu XIX iXX wieku (2013). Kontakt: agnieszka. dauksza@uj.edu.pl 
bardzo rozpoznawałam w tym siebie czy którąś ze znanych mi osób. Najładniejsze zdały się płuca palacza - wyglądały jak żyłkowany węgiel.

Widok tych obiektów domagał się wyrazu. Dosłownie - przez ich nazwanie i odniesienie do żywego ciała, jak i w próbie znalezienia słów dla tego doświadczenia. Leksykalna bezradność wiązała się z potrzebą komunikacji, momentem wyłaniania się języka narracyjnego i z rozpoznaniem ciała jako faktu materialnego. Świadczenie o przygodzie ciała konfrontującego się z materią preparatów patomorfologicznych było (i jest) sceną pierwotną dla mojego myślenia o humanistyce medycznej.

Każdy z aktantów społecznych ma wspomnienia, zwykle bardziej dotkliwe lub drastyczne, które angażują pamięć o naruszonym ciele, świadczą o chorobie własnej lub najbliższych osób. Coraz częściej stają się one przedmiotem artystycznego wyrazu, na co wskazuje rosnąca popularność patografii, obrazów „defektywnych" i ich opracowań'. W środowiskach lekarskich - zwłaszcza uniwersyteckich - coraz intensywniej rezonują pojęcia „medycyny narracyjnej” i „humanistyki medycznej”. Pierwsze określa tzw. dobre praktyki i teorie doskonalące opiekę zdrowotną, kształcące postawy nieredukcjonistyczne i antydyskryminacyjne w działaniach klinicznych, pomagające wypracować możliwie niehierarchiczny system odniesień między personelem a pacjentami ${ }^{2}$. Kluczowe są postulaty uważności, zaangażowania i dialogu. Style hermeneutycznego czytania literatury mają być inspiracją dla trybu leczenia opartego na detektywistycznej analizie przypadków. Istotne są założenia wypracowane w polu studiów humanistycznych: uznanie cudzej odmienności, próba wczucia się w specyfikę tego doświadczenia, holistyczne postrzeganie organizmu, przekonanie o wadze komunikacji z pacjentem w ustaleniu diagnozy, close reading jako sposób lektury dokumentacji itd. Metody te - wciąż wydające się nieosiągalnym ideałem w polskiej praktyce klinicznej - są stopniowo włączane do kanadyjskich, amerykańskich i zachodnioeuropejskich programów edukacji medycznej. Istotę tej działalności

1 Por. np. I. Boruszkowska Defekty, Literackie auto/pato/grafie - szkice, Wydawnictwo UJ, Kraków 2017; M. Ładoń Choroba jako literatura. Studia maladyczne, Wydawnictwo Naukowe „Śląsk”, Katowice 2019; Fragmenty dyskursu maladycznego, red. M. Ganczar, I. Gielata, M. Ładoń, Fundacja Terytoria Książki, Gdańsk 2019; S. Porzuczek Mapowanie bólu. Lektura, spojrzenie, afekt, Universitas, Kraków 2020.

2 Medycyna narracyjna. Opowieści o doświadczeniu choroby w perspektywie medycznej i humanistycznej, red. M. Chojnacka-Kuraś, Wydawnictwo UW, Warszawa 2019; Medycyna narracyjna. Teoria i praktyka, red. R. Charon i in., red. wyd. polskiego: M.K. Potoniec, H. Syzdek, Medycyna Praktyczna, Kraków 2020. 
dobrze oddaje fragment Jutrzenki Nietzschego przejęty przez Susan Sontag do wyjaśnienia przyczyn, dla których napisała Chorobęjako metaforę:

Rozmyślania nad chorobą! - Ukoić wyobraźnię chorego, by przynajmniej, jak to działo się dotychczas, nie cierpiał więcej skutkiem rozmyślania nad swą chorobą, aniżeli wskutek choroby samej - zdaje mi się, że to coś warte! I niemało! Rozumiecież teraz nasze zadanie?³

Humanistyka medyczna bywa rozumiana jako synonim medycyny narracyjnej, jednak intuicja wskazuje, że jej zakres znaczeniowy może być szerszy, a z pewnością jest mniej jednoznaczny. Jeśli medycyna narracyjna to forma działania naprawczego w systemie lecznictwa, to humanistyka medyczna jest formą kulturowej odpowiedzi na doświadczenie konfrontacji z tym systemem. Jestem przeciwna ograniczaniu rozumienia humanistyki medycznej jedynie do sfery odniesień (literaturoznawczych, filozoficznych, estetycznych, kulturoznawczych), które mogą służyć poprawie jakości relacji i usług zdrowotnych. Mimo idealistycznych założeń takie ujęcie sprowadzałoby ją do opowieści o historii zapożyczeń metod interpretacyjnych w leczeniu.

Sens tego terminu - być może również podstawową różnicę względem narracji medycznych - widzę przede wszystkim w jego potencjale krytycznym. Jest on zauważalny zwłaszcza wtedy, gdy traktuje się h u m a n i s ty kę me dy c z n ą jako zespół praktyk tekstowych, wizualnych i performatywnych, które problematyzują doświadczenie funkcjonowania (w) sieci zależności oddziałujących w ramach systemu klinicznego. Z tej perspektywy humanistyka medyczna to działania i opowieści świadczące o wykluczeniu, przemocy, bezsile, mobilizacji, emancypacji, krytyce i subwersji prowadzone z różnych, często antagonistycznych wobec siebie lub rywalizujących ze sobą pozycji, dotyczące z jednej strony pacjentów i tych, którym nie dane było zyskać tego statusu, z drugiej zaś personelu medycznego.

\section{Rozdzielona wspólnota}

Nie będę pisać o złych lekarzach, niepokornych pacjentach albo skutecznych lekarkach i pielęgniarkach. Interesuje mnie szerszy kontekst, w którym funkcjonują te postacie, system, który je wikła i bezpowrotnie zmienia. Społeczna

3 S. Sontag AIDS i jego metafory, w: tejże Choroba jako metafora. AIDS i jego metafory, przeł. .. Anders, Karakter, Kraków 2016, s. 95. 
i (bio)polityczna instytucja szpitali (również przychodni, hospicjów, sanatoriów, ośrodków opieki) wbrew pozorom wcale nie zrównuje pacjentów w chorobie, podobnie jak nie tworzy ahierarchicznej czy „klanowej” wspólnoty pracowników medycznych. Jedni i drudzy są natomiast częścią zmiennej wspólnoty emocjonalnej, w której stały jest tylko fakt permanentnego rozdzielenia w sensie, jaki nadaje temu pojęciu Jean-Luc Nancy: rządzą nimi nierówności, ale ich bycie, choroba, praktyka zawodowa i śmierć są jednako redukowane, "stają się nieznośnym ciężarem, a jednocześnie zatracają się w pospolitości i braku znaczenia"4. Wspólne jest odczucie bezsilności - tych, którzy są podpięci do aparatury medycznej, i tych, którzy są w fartuchach i ze specjalistycznymi narzędziami w ręku. Dotyczy to zarówno placówek uniwersyteckich, jak i samorządowych, oddziałów klinicznych, psychiatrycznych, diagnostycznych i zabiegowych5.

Jednak ta bezsilność z reguły nie tworzy podstawy do solidarności - opiera się na resentymencie, niechęci, wstręcie, nieufności. Argumenty są przewidywalne: $\mathrm{z}$ jednej strony zarzuty protekcjonalnego traktowania, nieuprzejmości, rutynowych, nieempatycznych zachowań, używania niezrozumiałego języka lub odmowy komunikacji; z drugiej - zarzut roszczeniowości, agresji, nadmiar bodźców, nieustanne zmęczenie, brak wsparcia od zespołu współpracowników, ciągłe wystawienie na ryzyko, które w niektórych przypadkach przybiera postać PTSD, wypalenie zawodowe, strach przed oskarżeniami i pozwami.

Obie strony mają swoje, skądinąd słuszne racje, obie są antagonizowane działaniami polityków, prawników i urzędników, piętrzącymi się ograniczeniami, biurokratycznymi wymogami, limitami środków i materiałów, absurdami prawnymi. Podobnie obie grupy funkcjonują w realiach skrajnego niedofinansowania: w złych warunkach przestrzennych i sanitarnych, przy niewystarczającej ilości sprzętu, w reżimie czasu, którego brakuje na kontakt z pacjentami, nie wspominając o rozmowie na temat historii choroby czy satysfakcjonującej opiece. Timothy Snyder w Amerykańskiej chorobie przekonuje:

4 J-L. Nancy Rozdzielona wspólnota, przeł. M. Gusin, T. Załuski, Wydawnictwo Naukowe Dolnośląskiej Szkoły Wyższej, Wrocław 2010, s. 9.

5 Dlatego analizuję w tym artykule "na równych prawach" odmienne konteksty chorowania i leczenia - narracje psychiatryczne, onkologiczne, neurologiczne, świadczące o nagłych interwencjach i chorobach przewlekłych itd. Sztuczne oddzielanie chorób i pacjentów - np. leczonych psychiatrycznie od tych "operacyjnych" - stygmatyzuje ich i nie służy poprawie dysfunkcyjnego systemu; bywa natomiast pretekstem dla strukturalnych i finansowych zaniedbań (vide status dogorywającej publicznej opieki psychiatrycznej w Polsce). 
„każdy pacjent ma swoją historię, ale nikt jej nie śledzi”". Można dopowiedzieć, że również nikt nie śledzi historii pielęgniarek i pielęgniarzy, salowych, ratowników, techników medycznych i lekarek. I nie chodzi o przekierowanie uwagi, usprawiedliwianie nadużyć czy zaniedbań, dopominanie się o współczucie wobec personelu, który powinien być przede wszystkim profesjonalny i niezawodnie służyć pacjentom. Chodzi o to, jak złożona jest sytuacja tych, którzy współtworzą sieć pomocy medycznej w Polsce:

Zatrudniłam się jako salowa w szpitalu w 2007 r. Sprzątam 50 gabinetów, schody, hole oraz 5 długich korytarzy. [...] Te prace, które teraz wykonuję, 20 lat temu robiły 4 osoby. Później te prace wykonywały 3 osoby, a jak firma zewnętrzna weszła, to już tylko 1. Jakbym miała codziennie solidnie wykonywać te prace, to proszę mi wierzyć, dnia by nie starczyło. Potrzebowałabym z pięciu. Tu nie pracują dziewczyny młode, np. po trzydziestce, młoda kobieta nie przyjdzie do sprzątania za 1,5 tys. zł. Tu pracują od czterdziestki prawie do sześćdziesiątki. Same kobiety z odzysku, po trudnych przejściach i niepowodzeniach. ${ }^{7}$

Chodzi wreszcie o psychofizyczne możliwości podlegania presji systemowych rozwiązań, hierarchiczne relacje, ciężar wymagań stawianych przez kapitalistyczne instytucje, które prześcigają się w maksymalizowaniu zysków nie tylko z pracy personelu, ale i z chorowania pacjentów. Te same instytucje bywają wciąż zapatrzone w najgorsze standardy PRL-owskiego funkcjonowania, z łapówkarstwem, kolesiostwem, mobbingiem i polityczną weryfikacją pracowników włącznie - a to wszystko w scenerii PRL-owskich wnętrz i niejednokrotnie przy użyciu narzędzi z tamtej epoki. Istotne są zatem ciągłości historyczno-materialne i to, jak rzutują na zależności poszczególnych aktantów w sieci medycznej. O złożoności problemu dobitnie świadczą Psy ras drobnych Olgi Hund:

Znam ten szpital, ten oddział, bardzo dobrze. Nosiłam tu mamie gazety, jedzenie i podpaski. Zawsze, jak ją odwiedzałam, to narzekała. Że wszystko stare, zaniedbane i nieszczelne. Że wiatr hula po korytarzu i po

6 T. Snyder Amerykańska choroba. Szpitalne zapiski o wolności, przeł. B. Pietrzyk, Znak Horyzont, Kraków 2021, s. 38.

7 Cytuję wypowiedź anonimowej rozmówczyni Katarzyny Dudy, autorki książki Kiedyśtu było życie, teraz jest tylko bieda. O ofiarach polskiej transformacji, Książka i Prasa, Warszawa 2019, s. 163. 
łazience, w której nawet kaloryfera nie ma i woda czasem zamarza. Ani zasłonki pod prysznic, ani żadnej szmaty, choćby takiej na okno, żeby nikt nie podglądał. Ani mopa do starcia jeziora od progu, bo w odpływach włosy. [...] No, ale po dotacjach unijnych jest tu zupełnie, zupełnie inaczej. Po pierwsze, pielęgniarki mają nowe makijaże. [...] Po trzecie, kompotu dają więcej, niż dawali mamie. Po czwarte, nowa łazienka (choć odpływ stary, ze starymi włosami i pewnie jakimiś nowymi). [...] Po szóste, dwa pudełka nowych i w ogóle niewybrakowanych puzzli. ${ }^{8}$

Zapychające odpływ włosy kolejnych pokoleń pacjentek są wyrazistą metaforą nieusuwalnej przemocy (nie tylko) symbolicznej, ale też materialnym dowodem ciągłości wieloletnich zaniedbań politycznych, strukturalnych i finansowych. Patografie to nie tylko opowieści o chorobie, ale i o patologicznych realiach, w których trudno o wyzdrowienie. Jak leczyć się z depresji i stanów lękowych bez prawa do intymności, w przestrzeni chaosu i brudu, dysfunkcyjnych rozwiązań, w ciągłym "niedomiarze" rzeczy i personelu, przy użyciu metod, w które nie wierzą nawet sami lekarze: „Robią mi test na depresję. Musi być bardzo stary. Jest odbitką przez kalkę z maszyny do pisania. Wygląda tak: Czy masz depresję? Zaznacz odpowiedź.TAK/NIE"’. I koniec testu.

\section{Patosystem medyczny}

Hund i jej bohaterki punktują kolejne absurdy działania szpitala psychiatrycznego. Scena pierwsza, w której lekarze, maskując bezradność metod profesjonalnych, wypracowują zestaw rytuałów magicznych (wtórnych, nie pierwotnych ${ }^{10}$ ): „Zdrowi psychicznie, czyli personel, wierzą za to, że kiedy spadnie na podłogę karta chorobowa, należy ją przydeptać, żeby pacjentka nie leżała długo"11. Scena druga, w której Ewa, jeden z najtrudniejszych „przypadków”, funkcjonująca w alternatywnym świecie odniesień, dziwi się bezmyślności nadkonsumpcji i nieekonomicznemu zużyciu energii w skądinąd biedującej instytucji: „Jest południe, dzień słoneczny, a na korytarzu zapalone światło, wszystkie lampy. Ewa mi je pokazuje. - Świecić, jak jest dzień - to jest

O. Hund Psy ras drobnych, ha!art, Kraków 2018, s. 11-12.

9 Tamże, s. 26.

10 Por. I. Morska Znikanie, Znak, Kraków, s. 32. 
rozum?”12. Scena trzecia: „Jest strajk. Pielęgniarki i salowe pozabierały nam prześcieradła i teraz na każdym budynku wisi poszprejowany łach z napisem Strajk. Bardzo mi się to podoba i - jak większość pacjentek - kibicuję, ale też obgaduję, że nam kible zamykają na pół dnia, bo nie ma kto pilnować, żeby się nikt na prysznicu nie powiesił"13. Czasoprzestrzeń strajku jest zarazem czasem i przestrzenią chorowania, jego oprawa wizualna została dosłownie wyciągnięta z łóżek pacjentek. Wyłom w funkcjonowaniu pracowniczek musi być też wstrzymaniem zachowań chorobowych, strajk jednych to gwałt na fizjologii drugich. Hund wskazuje materialne i symboliczne łącza między chorymi a leczącymi - łącza czy raczej płynne przejścia, sztuczność podziału na wspólnoty chorych i zdrowych, ich wzajemne oddziaływanie, „infekowanie” i trudność odnalezienia się w realiach patosystemu medycznego.

Chorowanie jest jedną z form bycia w społeczeństwie - stwierdza Aneta Żukowska, autorka Mięcha. Problem w tym, że społeczeństwo, choć jest w stanie permanentnej choroby, nie uznaje jej - nie chce i nie umie chorować. Co za tym idzie, nie daje przyzwolenia (sobie i innym) na słabość i bezradność, na chorowanie jako proces, ale też na satysfakcjonujący dostęp do opieki medycznej. Spora część społeczeństwa faktycznie sympatyzuje z politycznymi decyzjami o braku szerszej pomocy dla przewlekle chorych, niepełnosprawnych i ich opiekunów. Wielu - nie tylko pracodawców - każde zwolnienie lekarskie traktuje jako przejaw słabości, nadużycie czy nadwyrężanie finansów publicznych, „naszych podatków”. Oczywistością realiów późnego kapitalizmu jest kult sprawczości, atrakcyjności, młodości, witalności i mobilności, wypieranie chorych, starych, umierających ze sfery i przestrzeni publicznej, ale też zbiorowego imaginarium. Jedną z konsekwencji jest brak kulturowego przygotowania na chorobę. Rzecz jasna, nie sposób być na to w pełni przygotowanym, ale trening społeczny sprawia, że nie jesteśmy przygotowani w o g ól e, a doświadczenie choroby jest ostatnim, którego się spodziewamy - wydaje się ostatecznością.

„Nagle rozbłysło światło. Stałam przed wielką komisją" - tak przebudzenie w szpitalu wspomina w narracyjno-wizualnej opowieści Wołga przez Afazję Karolina Wiktor ${ }^{14}$. Sceny pierwszych konfrontacji to przede wszystkim opisy zależności i poczucia odrzucenia przez instytucję. W szpitalu

Tamże, s. 92.

Tamże, s. 110.

K. Wiktor Wołgą przez Afazję, ha!art, Kraków 2014. 
psychiatrycznym na drzwiach wejściowych informacja: „«Proszę dzwonić RAZ i cierpliwie czekać na otwarcie drzwi». Nie chcesz tu być, ale prosisz, żeby ci otworzono"15 - komentuje bohaterka Olgi Hund. Izabela Morska pisze o "małych ludziach zgniatanych przez chmury"16 i dodaje: „mam wrażenie, że wkraczam w krainę fikcji"17. Ta kraina to niekończące się kolejki, ciasnota, duchota, niepewność, ale i nuda czekania, rutyna powtarzanych procedur. Przygoda z systemem lecznictwa jest wejściem na inny tor czasu, który z perspektyw świata „zdrowych” zdaje się czasem straconym, „nicnierobieniem”, odpoczynkiem lub fanaberią. Doświadczenie wytrącenia z obiegu prezentuje Olimpia, film Katarzyny Kozyry z $1996^{18}$. Oczekiwanie na chemię, wkłuwanie w żyłę, przyjmowanie chemii, zmiana leków, reperkusje po chemii i kolejna chemia: te same przestrzenie, twarze, pozy, czynności. „Nic się nie dzieje”, gdy wokół wszystko idzie starym, szybkim tempem. Do tego bagatelizowanie symptomów przez otoczenie, z personelem włącznie, abstrakcyjnie odległe terminy wizyt - zwłaszcza na początku leczenia - i odczucie utraty kontroli, o którym pisze Żukowska:

jakość życia buduje się wśród ludzi, w świecie, który nie czeka, aż dołączę i nadążę. Już nie nadążę, już zawsze będę na innej pozycji. A oczekiwania, bym nadążyła, była jak inni, żyła jak inni, chorowała jak inni, tylko mnie rozpraszają, potęgują osamotnienie, hamują i tłamszą. [...] Chemia i śmiertelna choroba to "wieczny powrót tego samego", nieustanne odtwarzanie, w koło, raz jeszcze i tak samo boleśnie na nowo.To nie cichnie, do tego nie można się przyzwyczaić. Dlaczego więc nie ma na to przestrzeni, dlaczego muszę o nią nieustannie walczyć? Przede wszystkim w sobie samej. ${ }^{19}$

Doświadczenie słabości jest szokowe, ale ma całkiem konkretne podstawy: po pierwsze, nowa, trudna do oswojenia niemoc psychocielesna. Po drugie, bezradność wobec instytucji medycznej, jej przedstawicieli i „konkurencji”,

15 O. Hund Psy ras drobnych, s. 10.

Tamże, s. 22.

K. Kozyra Olimpia, film 12'4", 1996, https://zacheta.art.pl/pl/kolekcja/katalog/kozyra-katarzyna-olimpia.

19 A. Żukowska Mięcho, Karakter, Kraków 2019, s. 79. 
czyli innych pacjentów. Po trzecie, niewspółmierność między chorowaniem a wyzwaniami tzw. normalnego/zdrowego życia - pracą, sprawami rodzinnymi, zobowiązaniami finansowymi, towarzyskimi itd. Bezsilność łączy się z poczuciem zaklinowania - nie tylko w stanie chorobowym, ale też w inercji patosystemu, w którym znajduje się niewiele punktów oparcia ${ }^{20}$. Więcej, bezsilność pacjenta jest dla tego sytemu korzystna - dobry pacjent to pacjent pokorny, „skruszały” czy „spacyfikowany”:

wyników (w poradni onkologicznej) nigdy, przenigdy, przeprzenigdy nie daje się pacjentce do ręki. Wyniki oznajmia pani doktor. Co takiego? To była moja biopsja, moje ciało zostało dziabnięte czymś ostrym (i jeszcze dotąd trochę mnie pobolewa), umiem czytać, proszę mi dać tę „informację" [...]. W poczekalni było z grubsza milion ludzi, krzesełka zajmowały osobniki słabsze, reszta stała, gdzie się dało. Ściana za plecami (do podpierania) była miejscem uprzywilejowanym, większość jednak skazana została na stanie luźne i samoczynne, bez podpórek, pośrodku korytarza. To była druga lekcja cierpliwości, połączona z lekcją pokory. ${ }^{21}$

Czterogodzinne oczekiwanie Ewy Guderian-Czaplińskiej na informację o braku jednoznacznych informacji wiązało się z kolejnym aktem trenowania w pokorze: „Pani doktor uznała, że jestem niekulturalna i że ona rozumie frustrację, ale mam się zachowywać". Zachowywać się i czekać. Karnie stosować do wyznaczanych zasad i terminów. Zmienić tryb życia i dietę, zdrowo się prowadzić, nie stresować, dokształcać w chorobie, czytać o nowych metodach. „Dobra pacjentka nie truje się pretensjami. Nie wyraża zdziwienia. Jest rozrzutna, jeśli to konieczne” - ironizuje Morska: „uczę się, jak być dobrą pacjentką tak, jakbym uczyła się roli"22. Zwykle jednak w tej roli wypada się źle - Znikanie to opowieść nie tylko o bólu i postępującym niszczeniu dotychczasowego życia, ale też o stawaniu się „przezroczystą” dla kolejnych lekarzy. Morska wybiera strategię wyróżniania się (rozmową, zachowaniem,

Ten stan bywa z całą bezwzględnością wykorzystywany przez koncerny farmaceutyczne (suplementy i inne ekwiwalenty przepisanych leków), producentów środków homeopatycznych, wydawców (poradniki), niewykfalifikowanych medycznie doradców żywieniowych i rehabilitantów, znachorów, ale też sporą część nieprofesjonalnych usług oferowanych przez sektor prywatny.

E. Guderian-Czaplińska Trojanki, Media Rodzina, Poznań 2020, s. 15-16. 
zawodem), które może wywołać odruch empatyczny personelu lub chociaż zainteresować jej przypadkiem. Na dłuższą metę i ta metoda zawodzi, pacjentów jest zbyt dużo, czas i uwaga lekarzy są limitowane normami placówek i ministerstwa.

Choć dla wielu choroba i leczenie są przyspieszonym kursem samopoznania, biograficznym przełomem w odczuwaniu siebie jako bytu ucieleśnionego, to i tak w opowieściach dominuje frustracja powodowana wytrąceniem z egotycznego złudzenia wyjątkowości. Wiąże się to ze stopniowym uświadamianiem sobie, jak powtarzalny i nieinteresujący dla ogółu jest pojedynczy przypadek chorobowy. Christine Lavant zastanawia się nad swoim statusem: „Może każdy, kto przybywa tu jako pacjent, z tą chwilą traci własną duszyczkę na rzecz duszy grupowej?"23. I obserwuje rosnącą zależność chorych od personelu:

Tu człowiek naprawdę szybko przyzwyczaja się do wszelkiego rodzaju bolesnych incydentów i z czasem pojmuje lekarzy, którzy potrafią kwitować to wiecznie tym samym, życzliwie obojętnym uśmiechem. Niezwykłe i wstrząsające jest tylko, że każda twarz zawsze zwraca się ku nim z wyrazem oczekiwania i nieopisanej nadziei, jakby wkraczali zbawcy. Obserwowałam wszystkie, te najbiedniejsze, ale również te bardzo wytworne i powściaggliwe, wszystkie są do siebie podobne, jakby naraz nałożono im tę samą twarz. Z pewnością ze mną dzieje się nie inaczej, aczkolwiek mogę to stwierdzić tylko po rękach, które za każdym razem robią się niespokojne i wyglądają,jakby wreszcie mogły się czegoś przytrzymać. ${ }^{24}$

Hund także pisze o wytwarzających się w szpitalu powinowactwach wyglądu i objawów: „Jesteśmy bardzo podobne do siebie, [...] jedziemy wszystkie na jednym wozie"25. U źródeł tego podobieństwa jest bezsilność, tu rozumiana jako stan słabości zalegalizowanej instytucjonalnie, ale i wystawionej na ciągłą ingerencję innych. Jak w scenie interakcji pacjentki z pielęgniarką:

Nie inaczej, jako pierwsza użyła w stosunku do mnie tak tu powszechnej formy „ty”. Zakłuło mnie w sercu, jeśli wolno się tak wyrazić, nie,

C. Lavant Zapiski z domu wariatów, przeł. M. Łukasiewicz, Ossolineum, Wrocław 2017, s. 44.

Tamże, s. 64 . 
doprawdy, nie mogę inaczej nazwać tego drobnego, ale dotkliwego skurczu bólu. Usiadłam, a jakże, tu trzeba się słuchać. „Weź to”... Do wzięcia był blaszany kubek z wodą i owalna, dość duża pigułka. Ponieważ moja próba samobójcza odbyła się przy użyciu pigułek podobnego kształtu, myślałam właściwie, że już nigdy w życiu nie zdołam przełknąć pigułki, bo każdy nerw we mnie wzdragał się [...]. Ale siostra Marianna miała oczy jak z kamienia, a jej uśmiech wahał się na krawędzi, z której każdy uśmiech może ześlizgnąć się w groźbę, toteż mój opór natychmiast się załamał. Byłam potulna jak zwierze.. ${ }^{26}$

Repertuar praktyk patoklinicznych jest nieskończony: fizyczne i językowe niwelowanie dystansu, kiedy indziej budowanie go na potrzeby chwili - choćby przez zwracanie się do pacjentki w trzeciej osobie („to jest ta osoba?”, „niech się rozbierze”, „niech poczeka”), ograniczanie dostępności personelu, protekcjonalne lub obraźliwe traktowanie („Idę boso do dyżurki po pomoc. Drzwi są uchylone, otwieram je i wchodzę. - Puka się. Wróć i zapukaj”27). Opowieści szpitalne wskazują, że najbardziej typowe przejawy nadużywania przewagi przez personel to przemoc banalna, „pełzająca”, wynikająca nie tyle z perfidii czy sadystycznych skłonności, ile ze zmęczenia, nadmiaru, zblazowania. Zazwyczaj te stany objawiają się dziwnością czy nieadekwatnością zachowań - Lavant wspomina o pielęgniarce, która robiąc obchód, przystaje przy każdym łóżku „na dokładnie taką samą chwilę, jak gdyby wszystkie na równi tego wymagały, nawet puste łóżko zmarłej, nawet łóżko Magdaleny, która przecież leżała zasznurowana w komórce za ścianą"28. Ta nieadekwatność nie jest jednak neutralna, bywa dla pacjentek wprost deprymująca, jak w jednej z mocniej zapadających w pamięć scen z Psów ras drobrych, w której bohaterka uczestniczy w badaniu psychologicznym: „Wypełniam, a pani psycholog [...] ściaga laczki i cieliste rajstopy a potem maluje sobie paznokcie u stóp. Paluchy ma powyginane każdy w inną stronę, jak czułki. Wydaje mi się, że rejestrują każdy ruch w pomieszczeniu"29. Opresywność takich sytuacji nie wynika wyłącznie z przekroczenia zasad profesjonalizmu, rozmycia granic między przestrzenią publiczną (gabinetu konsultacji) a prywatną (czynności higieniczne). Kluczową kwestią jest odmowa dialogu

C. Lavant Zapiski, s. 58.

O. Hund Psy ras drobnych, s. 22. 
z pacjentką, wprost nieludzkie jej traktowanie - sprowadzenie do roli obiektu towarzyszącego „innym czynnościom”, którego odczucia i reakcje nie są istotne i którego nie trzeba się wstydzić.

Literatura patograficzna to zbiór scen świadczących o analogicznych aktach lekceważenia. Jednak w wielu przypadkach autorki nie uznają takich zachowań personelu za intencjonalne. Pojawiają się próby empatyzowania z kimś, kto sam nie jest zdolny do odruchów empatii. Morska interpretuje stan lekarzy jako traumatyczny stupor, zablokowanie na kolejne, nadto wymagające bodźce:

Wychodzę z wizyty, za którą zapłaciłam sto pięćdziesiąt złotych, z przekonaniem, że trafiłam na kolejny przypadek człowieka uszkodzonego na resztę życia na skutek traumy doznanej w prosektorium. [...] Pewnie od nikogo nie można wymagać sympatii dla trzydziestu sześciu ludzi, których widzi się codziennie w interwałach piętnastominutowych w ciągu jednego popołudnia. ${ }^{30}$

Snyder postrzega pracowników jako „niedoskonałych ludzi w niedoskonałym świecie"31, tak rozkojarzonych nadmiarem wyzwań i presji wywieranej przez przełożonych, że nie są w stanie nawiązać kontaktu wzrokowego, „dokończyć zdania, nie wspominając już o spojrzeniu na historię mojego przypadku"32. Snyder ocenia tę tendencję jednoznacznie: winny jest nie tylko klanowy (w gruncie rzeczy nadal feudalny i pełen uprzedzeń) układ pracy personelu medycznego, ale przede wszystkim niedofinansowanie placówek i usług oraz zbyt mała liczba pracowników: „to, że lekarze są udręczeni i popełniają błędy, leży w naturze naszego systemu”"33. Ostatecznie jednak nie chodzi o „więcej wiedzy” czy „lepszych lekarzy", ale o „lepszy system" na poziomie rozwiązań strukturalnych i znacznie prostszych, ,codziennych" praktyk. Dość przewidywalne postulaty Snydera komentującego w 2020 roku fatalny system opieki zdrowotnej w Stanach Zjednoczonych znacznie mocniej wybrzmiewają w eseju Lavant z połowy lat 30.XX wieku, w którym komentuje ona zasady funkcjonowania austriackiego szpitala psychiatrycznego, w tym przepisowe reakcje na zachowania pacjentów:

I. Morska Znikanie, s. 33.

T. Snyder Amerykańska choroba, s. 13.

Tamże, s. 32. 
zdumiewa mnie, że ci, których powołaniem tutaj jest koić i uśmierzać, nie poświęcają koniecznego czasu na to, by wczuć się w przedziwny tok myśli chorych i znaleźć miejsce wymagające interwencji. Na pewno byłoby to o wiele prostsze, niż się przypuszcza, a kilka odpowiednich słów zdziałałoby więcej niż zastrzyki i kaftan bezpieczeństwa. Ale może nie mam racji, na pewno nie, bo mnie już ta jedna [pacjentka] przywodzi niemal do desperacji, a na lekarzy czekają tu setki. Gdyby chcieli wczuwać się w każdego wariata, zatraciliby samych siebie. Jedyne, czego można żądać od ludzi, to unieszkodliwienie nas tutaj, całej reszty musi dokonać siła wyższa. ${ }^{34}$

Lavant dotyka sedna problemu, którym jest zasadniczy konflikt między potrzebami nieznacznych (czyli wszystkich) pacjentów a możliwościami personelu - ludzi, którzy niezależnie od jakości wykształcenia i przygotowania do zawodu mają ograniczone możliwości percepcji i uważności. Jednocześnie Lavant precyzyjnie wyznacza właściwą stawkę humanistyki medycznej: wczuć się, by „znaleźć miejsce wymagające interwencji”. Nie chodzi jednak o współczucie czy współodczuwanie - taka relacja z pewnością byłaby nieznośna, wprost niemożliwa fizycznie. Istotne jest zaangażowanie w każdy kolejny przypadek, otwartość myślenia o jego specyfice, nierutynowe podejście, które zwiększa szanse na kompleksową analizę, dostrzeżenie unikalności w tym, co powtarzalne. W praktyce jest to postulowanie uważności i dialogu, dzięki którym personel zyskiwałby dodatkowe dane (wbrew pozorom nie zawsze zafałszowane przez pacjentów). Dialog wpływałby też na kondycję psychiczną chorych, ograniczał liczbę interwencji i ponownych wizyt, minimalizowałby poziom obustronnej frustracji, konfliktów i pozwów.

Pod pewnymi względami niedużo zmieniło się od lat 30. XX wieku: wiele przypadków dałoby się wyleczyć, powikłań uniknąć, a ból zminimalizować, gdyby - o ile pozwala na to stan pacjenta - standardową częścią procedury medycznej była rozmowa, stanowiąca punkt wyjścia do szukania przyczyny złego samopoczucia. Na skalę problemu pośrednio wskazują statystyki: kilkanaście procent dzwoniących po pogotowie ratunkowe to ludzie, którzy chcą podzielić się swoim cierpieniem, umocnić, przełamać strach przed instytucją szpitala, wyjść ze stanu lękowego czy chociaż skonfrontować się z kimś, kto przez chwilę skupi się na ich położeniu. 
Istnieje grupa Polaków, która korzysta z pomocy pogotowia ratunkowego kilka razy w miesiącu, wykonuje wysokospecjalistyczne badania kilka lub kilkanaście razy do roku, spędza znaczną część życia w kolejkach do lekarzy. Nie zawsze są po temu wskazania medyczne, niekiedy takie działania wynikają z inwencji i (nad)aktywności samych pacjentów, mają charakter prewencyjny: „na wszelki wypadek”, „kiedyś się przyda”, „może coś znajdą”. Grupa ta bywa określana mianem hipochondryków, niezrównoważonych emocjonalnie, hipokrytów społecznych czy naciągaczy „zużywających” publiczne środki. Ciekawie byłoby jednak rozważyć takie zachowania - tu jedynie sygnalizuję możliwą perspektywę - w innych kategoriach, np. próby awansu czy emancypacji społecznej. Dlaczego o niektórych mówi się, że na widok lekarza, pielęgniarza bądź ratownika od razu czują się lepiej? Ryzykując nadmierną generalizacją, można uznać, że dla części pacjentów obecność w przestrzeni opieki medycznej lub kontakt z jej reprezentantem są wyróżnieniem. Być może uznają to doświadczenie za jeden z nielicznych (pozornie) bezpłatnych, w miarę dostępnych przywilejów społecznych. Może ważny jest sam fakt uznania przez instytucję ich istnienia - ich, ludzi nieznacznych, którzy zyskują status pacjenta. Zapewne liczy się także zmiana symboliczna: przez obecność w szpitalu można wpisać się w system odniesień znaczących, zaistnieć w dokumentacji i kartotekach, zostawić po sobie ślad. Jak bohaterki Psów ras drobnych - „gdyby nie papiery: dokumenty z domów dziecka, poprawczaków i więzień, wypisy ze szpitala, niebieskie karty i recepty [...] nikt by nie pamiętał, że te kobiety, które dzisiaj są tutaj, w ogóle żyły"35.

$\mathrm{Z}$ tej perspektywy każde kolejne badanie, konsultacja, interwencja, pobyt w placówce są zdobyczą, oznaką fortunnej przedsiębiorczości pacjenta lub pacjentki, pięciem się w tej swoistej hierarchii bywalców: zyskiwaniem „zwiedzonych" gabinetów, „poznanych” lekarzy, „wyleżanych” miejsc szpitalnych. Nie świadczy to jednak o roszczeniowości ludzi nieznacznych, ale o stanie samego systemu medycznego i przede wszystkim o tym, od czego jest zależny, czyli świeckiej, przyziemnej „siły wyższej”, jak określa ją z melancholijną ironią Christine Lavant.

\section{Projekt mobilizacja}

„Będzie pan zdrów w parę miesięcy i pański duch/ochota życia zrobią dla pana więcej niż my" - zapewniał pacjenta lekarz z poematu Mariana 
Czuchnowskiego, po czym „powiedział dobranoc wyskoczył jak z procy/zgasił górne światła zamknął drzwi"36. Mikroscena ze szpitalnego życia pośrednio wskazuje na szereg niedobrych praktyk klinicznych. Jedną z nich jest podwójna gra, czyli ciągła oscylacja między ćwiczeniem pacjentów w uległości a komunikatami o charakterze mobilizującym. Sontag przedstawia repertuar metod "militaryzowania" choroby i przekonuje o nieadekwatności metaforyki wojennej stosowanej powszechnie w dyskusji o chorujących - mowa np. o zmaganiu się z chorobą, porażce, przegranej walce, bohaterach, ofierze, odparciu wroga, heroicznej walce, ewentualnie zwycięstwie. Badaczka punktuje mankamenty takiej strategii: po pierwsze, pojawia się sugestia, że choroba to zawsze czynnik zewnętrzny, ,,coś obcego", po drugie zaś,,,metafory wojskowe przyczyniają się do stygmatyzacji niektórych chorób", a przez to dotykają i samych chorujących ${ }^{37}$. Tropem Sontag podąża Żukowska, uznając, że w kulturze współczesnej chorowanie traktowane jest jako sprawdzian lub kara za „złe życie”. Jakby traumatyczne doświadczenia, nadmiar stresu, pesymizm, tłumienie, nieodpowiednia dieta, słabości i narażenie na szkodliwe warunki atmosferyczne były kwestią świadomego wyboru ${ }^{38}$. Realny problem pojawia się, gdy mobilizacja przeradza się w formę bezmyślnej krytyki kierowanej wobec pacjenta, roszczeniowego oczekiwania na znaczne postępy w leczeniu, ledwo tajonej agresji, dominacji społecznej, która czyni z konkretnej choroby sprawę całej zbiorowości. Żukowska stwierdza wprost: granica między mobilizacją a zmuszaniem do leczenia jest cienka jak papier ${ }^{39}$. Sprzeciwia się również działaniom personelu medycznego i bliskich - kolejnym gestom aktywizowania, pocieszania i umacniania, które mają z niej uczynić dzielną pacjentkę. Metody interpretacyjne wypracowane przez Michela Foucaulta skłaniają do pytania, kto za nas „mówi” w takich sytuacjach, co w istocie "robi” dyskurs militarystyczny w medycynie i jaki ma wpływ na chorujących ${ }^{40}$.

Tym, co przede wszystkim gnębi patosystem medyczny - zapewne nie tylko w Polsce - są trzy tendencje: skrajna kapitalizacja usług, oddziaływanie

36 M. Czuchnowski Szpik egzystencji, Oficyna 21, Warszawa 2017, s. 218.

37 S. Sontag AIDS i jego metafory, s. 93.

38 S. Sontag Choroba jako metafora, w: tejże Choroba jako metafora. AIDS i jego metafory, s. 44-73;

A. Żukowska Mięcho, s. 12-15. rządek dyskursu, przeł. M. Kozłowski, słowo/obraz terytoria, Gdańsk 2002. 
nierówności klasowych oraz patriarchalne odruchy i przyzwyczajenia. Wszystkie te tendencje zbiegają się w projekcie wielkiej mobilizacji, która wyznacza kierunek funkcjonowania placówek medycznych. Za każdym razem gdy wbrew logice i możliwościom chorych - wmawia się im konieczność przełamania słabości i walki za wszelką cenę, wykorzystywane są nie tyle spontaniczne argumenty „z głębi serca”, ile narzędzia i retoryka nowoczesnych idei postępu, rozwoju, maksymalizacji zysków. Instytucje medyczne interpelują i mobilizują pacjentów, gdyż kolejne przypadki wiążą się z dodatkowym finansowaniem ministerialnym (każdy przyjęty pacjent i wykonana procedura oznaczają zysk dla szpitala). Jednocześnie przez skuteczną mobilizację uwalniają się od presji oczekiwań lub oddalają od siebie odpowiedzialność przynajmniej na poziomie symbolicznym. Kluczowa jest sugestia, że to dobra wola pacjenta i jego najbliższych, sprawne działania, terminowość, własna inicjatywa, prywatne środki i kreatywność w poszukiwaniu metod przyczynią się do wspólnego sukcesu i wyzdrowienia. Jeśli proces się nie powiedzie, pozostaje argumentacja, że pacjent był nie dość przedsiębiorczy, otoczenie nie wsparło go należycie, zbiórka funduszy została zorganizowana zbyt późno, bohater okazał się niebohaterski, a zewnętrzny wróg pokrzyżował szyki. Chorzy są zatem po raz kolejny wpisywani w porządek kapitalistycznych odniesień, w którym przeżycie zależy od: metodycznych starań, obrotności, wyczekiwania, gdy jest to wskazane, wzmożenia wysiłków, gdy dostaną odpowiedni sygnał, a nade wszystko hierarchicznej pokory i aktywnej cierpliwości.

Wbrew pozorom nie są winni ci, którzy na co dzień reprezentują układ medyczny i bezpośrednio przekazują tego typu komunikaty - w każdym razie nie na poziomie jednostkowym. Oni także wpisani są w ten dyskurs i uwewnętrzniają mechanizmy kulturowe podtrzymujące inercję patosystemu. Pracownicy nie są beneficjentami służby zdrowia - są dosłownie służebni. Widać to zwłaszcza w sytuacjach zachwiania pozornej równowagi, w czasie strajków, protestów, stanów wyjątkowych, zasadniczych zmian prawnych czy epidemii. Na poziomie retoryki tendencje zmieniają się błyskawicznie: personel przestaje być pracowitą, świetnie wykształconą chlubą narodu, staje się przeciwnikiem w grze politycznej, wrogim elementem, przywykłym do luksusów i prestiżu wyłudzaczem środków publicznych.

Projekt mobilizacji obejmuje wszystkich aktantów instytucji medycznej. Po pierwsze, im więcej pacjentów, tym większy zysk danej placówki; nie ma choroby, na której nie dałoby się zarobić. Po drugie, istnienie instytucji zależne jest od mocy przerobowych, personelu na ogół nie zachęca się więc do starań o jakość pomocy i zaangażowanie w poszczególne przypadki, ale 
do maksymalizowania wysiłków (szybkości i wydajności wykonywanych działań, pracy po godzinach, na kilku etatach i kontraktach). Co więcej, nie ma w gruncie rzeczy procedur, które oceniałyby jakość i efekty świadczeń, liczy się sam fakt realizacji (i minimalizacja ryzyka powikłań). Raportowanie błędów nie jest czymś oczywistym. Nie istnieje też kultura pracy w zespole - nie obowiązują zasady współodpowiedzialności i wzajemnej, partnerskiej oceny działań. Wszelka krytyka traktowana jest ambicjonalnie, ale też - jeśli w ogóle się pojawia - ma charakter odgórnego upomnienia. Z tej perspektywy polska służba zdrowia wciąż funkcjonuje w hierarchicznym modelu patriarchalnej, maczystowskiej dominacji, opierającym się na symbolicznej i finansowej przewadze dyrektorów, prezesów, ordynatorów, dalekim od sieciowego modelu „płaskich” relacji, które ułatwiałyby wypracowanie mechanizmów (auto)krytyczności i współdziałania.

W rezultacie praktyk mobilizacyjnych wieloletnie zaniedbania strukturalno-finansowe w edukacji i praktyce medycznej są (w miarę) łatane (nad)aktywnością zbyt małej liczby pracujących. Koszt społeczny jest ogromny: kolejne grupy są wykorzystywane do bieżących celów politycznych, potęguje się frustracja personelu i pacjentów, pogłębia się brak wzajemnego zaufania i szacunku, błędy i konflikty są rozstrzygane głównie na drodze prawnej (co wzmacnia pozycję prawników, którzy de facto kierują instytucjami medycznymi).

Stan rzeczy ułatwia zarządzanie oparte na antagonizmach - np. ratowników, pielęgniarzy, salowych i rehabilitantów łudzi się, że przy zwiększonej efektywności kiedyś dobiją do poziomu zarobków lekarzy. Anestezjologom obiecuje się perspektywy, jakie mają chirurdzy. Lekarkom wmawia się, że medycyna nie jest dla nich dyscypliną oczywistą, więc muszą się starać bardziej niż lekarze. Dzielenie grup znajduje też zastosowanie wobec pacjentów: młodzi mają większe szanse na zabiegi niż ludzie starsi; ci, którzy korzystają z wizyt prywatnych, dostają szybsze terminy zabiegów w placówkach publicznych; pacjentki notorycznie przekonuje się, że są bardziej odporne na ból niż pacjenci (nie potrzebują więc środków przeciwbólowych), ich objawy są niewyraziste, a motywacje i autodiagnozy mętne $e^{41}$.

\section{Różowe rękawiczki (kolektyw bólu)}

Opowieści szpitalne rejestrują podziały i wykluczenia w dostępie do pomocy, jak również ich społeczno-ekonomiczne zależności. Na pierwszy plan 
wysuwa się rzecz jasna klasowość nie samego chorowania, ale metod radzenia sobie z oporem systemu i świadczenia o tym procesie. Kluczowe są zasoby finansowe i dostęp do prywatnego sektora medycznego, ale też koneksje, a nade wszystko łatwość zjednywania nowych kontaktów, mobilność, dostęp do baz danych $\mathrm{i}$ ich analizy. Oczywiście znaczna część chorych nie jest w stanie sprostać tym wymaganiom. Patografie przełomu XX i XXI wieku ukazują cały repertuar postaci nieznacznych w ich kruchości i rozczarowaniu realiami:

Wszyscy błądzą w dokumentach, skierowaniach, szukają właściwych drzwi i właściwej kolejki. Każdy chce uciec, wyjść jak najszybciej, ale tutaj można się już tylko zgubić. Unieruchomienie w systemie, który powoli trawi i przesuwa, by wreszcie skierować dalej lub rozłożyć ręce w geście bezradności, wyrzucić z siebie, odesłać do domu. Z ponownym zaproszeniem lub już bez zaproszenia. ${ }^{42}$

Teksty kultury podsuwają rozmaite scenariusze losów tych, którzy zostają odtrąceni przez instytucję. Najczęściej giną niemal bez śladu, bywa jednak, że odmowa leczenia jednostki odbija się na funkcjonowaniu wspólnoty, jak choćby w Jokerze Todda Phillips'a (2019), w którym brak wsparcia psychiatrycznego dla głównego bohatera doprowadza do szeregu zabójstw. Polskie opowieści medyczne ostatnich lat to przede wszystkim historie kobiet, które nie tyle szkodzą życiu zbiorowemu, ile same zostały przez wspólnotę poszkodowane. Ich doświadczenia i objawy nie są widowiskowe, ot, kolejne ofiary presji ekonomicznej i dominacji patriarchatu: „większość dziewczyn na oddziałach nie jest aż tak szalona i pamięta, co robili im ojcowie, wujkowie, mężowie, matki, co robił im Kościół, ZUS i rynek pracy”43. Bite „po pyskach przez mężów-wężów”, następnie opuszczone w chorobie, owszem, „mają zwidy, ale też długi i eksmisje"44.

Patografie to także świadectwo upokorzeń w placówkach medycznych, które nie stanowią schronienia przed rzeczywistością społeczną. Diagnozy literackie wskazują, że wspólnoty szpitalne zachowują wszystkie cechy podzielonego społeczeństwa, ale niechciana bliskość ludzi zamkniętych we

\footnotetext{
42 A. Żukowska Mięcho, s. 62-63.

43 O. Hund Psy ras drobnych, s. 49.

Tamże, s. 40 i 106.
} 
własnym cierpieniu eskaluje skłonności przemocowe: „widać wrogością najłatwiej się zarazić" ${ }^{45}$. Mobilizacyjna polityka instytucji i konflikty między pracownikami nakręcają atmosferę rywalizacji. W najlepszym razie w końcu wytwarza się rutynowe zobojętnienie: „żaden nie związany z żadnym ani sympatią, ani niechęcią"46. Żukowska dodaje: „za daleko, by ze sobą rozmawiać, a jednak zbyt blisko, by nie odczuwać swojej obecności, chociażby przez spojrzenia" ${ }^{47}$. Postacie przypominają rzeźby Giacomettiego z przełomu lat 40. i 50. (Kwadrat, Polana, Las): odizolowane figury, które wyrastają z tej samej podstawy. I choć opowieści pacjentek sugerują, że szpital to przestrzeń, która prowokuje, by „zadawać największy możliwy ból”"48, to jednocześnie te same narracje podsuwają konkretne scenariusze zaradcze.

U podstaw są niezgoda i gniew - bez tych trudno o samopomoc, a bez tej nie sposób przetrwać w patosystemie. Zaczyna się od kolejnej niesprawiedliwości, doznanej lub obserwowanej, wszystko jedno, bo w pewnym momencie - wbrew podziałom - ciało pacjentki zaczyna funkcjonować jako ciało kolektywne:

[Magdalena] wbrew przestrogom wciąż drapała się do krwi, aż sprowadzono dwóch pielęgniarzy z oddziału męskiego, żeby przy ich bezwstydnie brutalnej pomocy założyć biedaczce kaftan bezpieczeństwa. Nie wiem, czy to naprawdę było konieczne, ale na pewno nie musiało się odbyć w taki sposób, bo dotykając jej piersi, nie zachowywali się jak pielęgniarze, lecz jak mężczyźni, i robili to z przyjemnością. [...] Zapisuję to zwyczajnymi słowami, zapisuję, jakby to nie było nic szczególnego, a właściwie powinna bym rozwalić te ściany i kamień po kamieniu ciskać. $^{49}$

Jednocześnie odczucie ciała kolektywnego jako własnego to moment zapalny, bodziec do krytyki i działania. Przede wszystkim do starań o prawo do intymności współpacjentek, do przyzwolenia na słabość, odmowy heroizmu lub decyzji o nieprzetrwaniu (Żukowska). Poza tym do uruchomienia

C. Lavant Zapiski, s. 11.

O. Hund Psy ras drobnych, s. 43.

A. Żukowska Mięcho, s. 20. 
wspólnoty kolejkowej, obiegu „praktycznych rad z korytarza”, siostrzanej wymiany (Guderian-Czaplińska), aktywacji oswajających pojęć „na własny użytek" ${ }^{\text {" }}$, rozwinięcia "tymczasowej sieci wsparcia” (Morska). Wreszcie do literackich i wizualnych opowieści tworzonych „w reakcji” - tych, które przewodzą w tym tekście refleksji o humanistyce medycznej, ale i dzieł Anny Świrszczyńskiej, Haliny Poświatowskiej, Ewy Kuryluk, Joanny Mueller, Marii Jaremy, Aliny Szapocznikow, Katarzyny Kozyry, Joanny Rajkowskiej i wielu, wielu innych. Ich głosy łączą się w mocny komunikat, który wprost wyraża Hund: „ani Czarna, ani ja, ani nikt tu nie ma siły nigdzie uciekać"s1. Bo i dokąd? Ale też: dlaczego znowu my? Uważność wobec tych głosów uświadamia, że to, czego nie robią politycy, urzędnicy, prawnicy, ordynatorzy i szeroko pojęty system medyczny, wypracowują kobiety - pacjentki i opiekunki. Szapocznikow poprzez asamblaże, np. Różowe rękawiczki (1970) i Popielniczkę słomianego wdowca I i II (1972), w których fragmentaryzacja kobiecego ciała sugeruje nieholistyczne postrzeganie przypadków chorobowych, napięcie między dotykiem, dotkliwością i niedotykalnością, nieciągłości między funkcjonowaniem obiektu seksualnego, pacjentki i chorej o „wypalonym” potencjale. Kozyra, która prezentując Olimpię (film i trzy fotografie), podejmuje dialog z Szapocznikow i pyta o status chorych i starych kobiet w społeczeństwie spragnionym przyjemności, sprawczości i (nad)konsumpcji. Wreszcie Rajkowska z performansem Pozwól, że umyję ci ręce (1994) ${ }^{52}$, która za pomocą podstawowego środka - ,zmysłowej” jodyny - wprawia w ruch granicę prywatnego i publicznego, dotykanego i dotykającego, ale też problematyzuje trudne napięcie między kontaktem profesjonalnym a intymnym, działaniem prozdrowotnym i przyjemnością.

Ich opowieści tworzą wyłom $\mathrm{w}$ reprodukowanym mechanizmie niedobrych praktyk: mediują między porządkami pojedynczości i powtarzalności, intymności i kolektywności, tworząc połączenie, które de facto nie istnieje w rzeczywistości doświadczeniowej. Raz jeszcze przekonuje o tym Lavant: „Ostatecznie chodzi przecież tylko o tę warstwę pośrednią, o coś pomiędzy własną wrażliwością a tym, co do nas dociera. No tak, wyrażam się doprawdy niemal jak filozof, a przed chwilą leżałam tam jak przedmiot wystawiony na

50 E. Guderian-Czaplińska Trojanki, s. 12.

51 O. Hund Psy ras drobnych, s. 108.

52 J. Rajkowska Pozwól, że umyję ci ręce, film 21'47', 1994, http://www.rajkowska.com/pozwol-ze-umyje-ci-rece-wideo. 
pokaz" ${ }^{33}$. Jeśli doświadczenie szpitala to przede wszystkim bezradność i zależność, literackie i artystyczne świadectwa kobiet ustanawiają nową relację między nadużyciem (tam, wtedy) a niezgodą (tu, teraz). Ta relacja - „warstwa pośrednia" - bywa barierą ochronną, może jednak stać się również punktem oparcia dla innych: płaszczyzną afektywnej i doświadczeniowej wymiany. Nieistniejące, ale już możliwe do pomyślenia połączenie jest polem potencjalności humanistyki medycznej.

\section{Abstract}

\section{Agnieszka Dauksza}

JAGIELLONIAN UNIVERSITY (CRACOW)

The Medical Humanities: On Healing (Oneself) in a Pathosystem

Dauksza (re)defines the medical humanities and outlines its framework in contemporary culture. She conceptualises it as an ensemble of textual, visual and performative practices that problematise the experience of functioning in the institution of the hospital. Literary and artistic narratives by women (e.g. Christine Lavant, Olga Hund, Aneta Żukowska, Alina Szapocznikow, Katarzyna Kozyra, Joanna Rajkowska) allow Dauksza to discuss the different functions of the medical humanities: to criticise the health care system, to testify and to offer strategies of repairing/salvaging. She examines the relationships between different factors within the clinical system, their helplessness and their dependence on politics, class and economy. While exploring the violence that affects patients and health care workers in the system, Dauksza also points to forms of women's collective self-help, which is the true focus of the medical humanities.

\section{Keywords}

medical humanities, health care, medical care, women's literature, helplessness, illness 